\title{
Cationic Host Defence Peptides: Potential as Antiviral Therapeutics
}

\author{
Emily Gwyer Findlay $\cdot$ Silke M. Currie $\cdot$ \\ Donald J. Davidson
}

Published online: 7 May 2013

(c) The Author(s) 2013. This article is published with open access at Springerlink.com

\begin{abstract}
There is a pressing need to develop new antiviral treatments; of the 60 drugs currently available, half are aimed at HIV-1 and the remainder target only a further six viruses. This demand has led to the emergence of possible peptide therapies, with 15 currently in clinical trials. Advancements in understanding the antiviral potential of naturally occurring host defence peptides highlights the potential of a whole new class of molecules to be considered as antiviral therapeutics. Cationic host defence peptides, such as defensins and cathelicidins, are important components of innate immunity with antimicrobial and immunomodulatory capabilities. In recent years they have also been shown to be natural, broad-spectrum antivirals against both enveloped and non-enveloped viruses, including HIV-1, influenza virus, respiratory syncytial virus and herpes simplex virus. Here we review the antiviral properties of several families of these host peptides and their potential to inform the design of novel therapeutics.
\end{abstract}

\section{Antiviral Peptide Treatments}

Viral diseases are a leading cause of morbidity and mortality worldwide, particularly of children [1], and yet development of effective therapies is slow. In particular, progress is hampered by the fact that the majority of antiviral drugs are specific for only one virus. Current approaches are expensive, require rapid identification of

E. Gwyer Findlay · S. M. Currie · D. J. Davidson $(\square)$ MRC Centre for Inflammation Research, Queen's Medical Research Institute, The University of Edinburgh, 47 Little France Crescent, Edinburgh EH16 4TJ, Scotland, UK

e-mail: donald.davidson@ed.ac.uk the virus before therapy and, at the initial stages of development, involve enormous redundancy of research effort. This also results in efforts being concentrated on a few viruses; of the 60 antiviral drugs that have so far been approved by the US Food and Drug Administration (FDA), almost half target HIV-1; the remaining half are used for the treatment of hepatitis B virus (HBV), herpes simplex virus (HSV), varicella-zoster virus (VZV), cytomegalovirus (CMV), influenza (IAV) and hepatitis $\mathrm{C}$ virus (HCV) infections [2].

These factors, in combination with the rate of development of drug resistance, mean that there is an urgent need for new broader-spectrum intervention strategies. It is therefore exciting that in recent years a new class of antiviral therapeutic peptides are emerging, with 15 peptidebased intervention strategies against viruses currently in various stages of clinical trials [3]. Peptide-based strategies are proposed to be cost-effective, with peptides having low molecular weights, rapid elimination following treatment, and low levels of side effects [3].

An exciting current area of advancement is in understanding the antiviral properties of naturally occurring cationic host defence peptides (CHDPs) and the capacity of this to inform the design of novel synthetic antiviral analogues. In this review we will give an overview of the antiviral activities of CHDPs and consider their potential in the development of broad-spectrum antiviral therapeutics.

\section{Cationic Host Defence Peptides}

CHDPs, also known as antimicrobial peptides, are an essential part of the innate immune response, with both direct microbicidal and pleiotropic immunomodulatory properties [4-6]. Their fundamental importance to host 
defence against infection is emphasised by their conservation across plants, insects, reptiles, birds and fungi [7]. In mammals the two major families of CHDPs are defensins and cathelicidins.

\section{$2.1 \alpha$-Defensins}

Defensins are cationic, amphipathic peptides generated from prepropeptides via proteolysis and are categorised within three subfamilies: $\alpha, \beta$ and $\theta$. Defensins were first characterised as "natural peptide antibiotics" with the discovery of $\alpha$-defensins from the granules of neutrophils [8].

The $\alpha$-defensin family has been identified in a range of higher eukaryotes (including primates, mice, rats, guinea pigs and rabbits) and comprises six distinct peptides in humans (human neutrophil peptides (HNP) 1-4 and human defensins (HD) 5-6), expressed from five DEFA genes [9]. All have a triple-stranded $\beta$-sheet core stabilised by three intramolecular disulphide bonds, and are made first as a prepropeptide which is proteolytically cleaved to the active form [10]. In the case of HD5 and HD6 the key protease is trypsin. HNP1-4 are produced mainly by neutrophils, where they comprise $5-7 \%$ of total neutrophil protein [11], and neutrophil precursors in the bone marrow [12]. HNP1-3 are also described in NK cells, B cells, $\gamma \delta \mathrm{T}$ cells, macrophages and immature dendritic cells [13], but can be acquired from neutrophils [14]. The release of active HNPs from neutrophil azurophilic granules can be induced by a range of stimuli, including chemokines, FC gamma receptor cross linking, PMA and TLR stimulation [13]. In contrast, HD5 and 6 are expressed by Paneth cells of the small intestine [15, 16] and epithelial cells of the female genital tract $[12,17$, 18]. Interestingly, although mice express a large number of intestinal $\alpha$-defensins (cryptdins) [19], in contrast to humans they do not express $\alpha$-defensins in their neutrophils [20, 21].

$\alpha$-Defensins have well-described broad spectrum antimicrobial activity against both Gram-positive and -negative organisms in vitro [22], with cationicity and hydrophobicity being shown to be key determinants of these properties [9, 23]. Their cationic charge is proposed to enable interaction with the net negative charge on the surface of the Gram-negative bacteria and the teichoic acids of the Gram-positive organisms, while their amphipathic structure enables insertion into and disruption of the bacterial membranes, leading to lysis of the cells. In addition, various $\alpha$-defensins are described as having additional, non-microbicidal properties, including chemotaxis for effector cells of the innate and adaptive immune systems [24, 25], inhibition of macrophage pro-inflammatory cytokines [26], modulation of the intestinal microbiome [27] and the formation of protective peptide nanonets [28].

\section{$2.2 \beta$-Defensins}

The $\beta$-defensin family contains more than 30 members in humans and more than 50 in mice, and are widely expressed across many species, in particular being the only defensins found in birds and with close homologues present in snakes, platypus and sea anemones [29]. They are also triple-stranded $\beta$-sheet proteins, but differ from the $\alpha$-family members in the organisation and arrangement of the three disulphide bonds [10]. The most well characterised human $\beta$-defensins are human $\beta$-defensin (HBD) $1-3$, expressed by epithelial cells [30], monocytes, macrophages and macrophage-derived DC [31]. HBD1 is encoded by $D E F B 1$ and is expressed constitutively [30], whereas expression of HBD2 (DEFB4A) and HBD3 (DEFB103A) are up-regulated in response to various inflammatory stimuli, including microbes [32], TLR and NOD proteins [33] and pro-inflammatory cytokines [34].

$\beta$-Defensins are also described as having broad-spectrum antimicrobial activity in vitro [7], with potency varying in different family members. Interestingly, the weak microbicidal properties of HBD1 were recently shown to be greatly enhanced upon reduction of its disulphide bonds [35]. Although relatively mild phenotypes were found in mouse models deficient in Defb1 [36, 37], redundancy in this multi-gene family may be responsible for this observation. In addition $\beta$-defensins are described as having a range of immunomodulatory properties, including chemotaxis of $\mathrm{CD}^{+}$memory $\mathrm{T}$ cells, macrophages and immature dendritic cells [38], enhancement of wound healing [39] and the modulation of inflammatory cytokine responses (with the capacity both to promote and to suppress inflammation in different settings) [40].

\section{$2.3 \theta$-Defensins}

$\theta$-Defensins are circular octadecapeptides, the only circular peptides of mammalian origin [41], formed by the splicing of two nonapeptides, each of which contributes three cysteines to a series of disulphide bonds in the mature peptide [42]. Three $\theta$-defensins have been found in the leukocytes of rhesus macaques and named RTD1-3, but although six RNA transcripts homologous to RTD are found in the human bone marrow they contain a premature stop codon preventing their expression [42, 43]. However, an artificially constructed peptide based on these pseudogenes, called retrocyclin, has been studied with respect to its function and therapeutic potential and shown to kill Escherichia coli in the same way as $\alpha$-defensins, by permeabilising its membrane [44]. 


\subsection{Cathelicidins}

The cathelicidin family is quite distinct from defensins; cathelicidins are defined by a conserved cathelin domain and with a variable C-terminal region, which is proteolytically cleaved to produce a mature functional peptide, with a range of structural forms in different family members [45]. In contrast to the extensive defensin family, humans (and mice, rats and rabbits) express a single cathelicidin, whereas multiple cathelicidins are found in other species (e.g. protegrins in pigs). The sole human cathelicidin, human cationic antimicrobial peptide of $18 \mathrm{kDa}$ (hCAP-18; encoded by the CAMP gene), is cleaved by proteinase 3 into its active form, LL-37, which is a cationic, amphipathic peptide of $4.5 \mathrm{kDa}$ with an $\alpha$-helical structure [46, 47]. hCAP-18 is stored in neutrophil-specific granules, inducible in epithelial cells, macrophages and other leukocytes to a lesser extent, and detectable in a range of body fluids, including airway surface liquid, plasma, urine, breast milk and sweat [48]. It is up-regulated in response to infectious and inflammatory signals [49] and wounding [50] and its expression can be increased by vitamin $\mathrm{D}$ metabolites [51] and compounds such as butyrate [52].

LL-37 has well-documented antibacterial potential; however, when studied in the presence of physiological concentrations of cations or serum, LL-37 has high minimum inhibitory concentrations compared to levels described in vivo [6]. Mice deficient in mCRAMP (encoded by the Camp gene, the orthologue of CAMP) have increased susceptibility to infections in multiple systems, including the skin, intestinal tract and lung [53-55]. Although these models clearly demonstrate the critical role for cathelicidin in host defence against infection, it remains unclear to what extent this is due to microbicidal or modulatory properties of the peptide. LL-37 has been shown to have a broad range of immunomodulatory and inflammomodulatory properties [6]. These include chemotactic activity for neutrophils, monocytes and $\mathrm{T}$ cells [56], modulation of cytokine production [57], effects on dendritic cell differentiation and function [58, 59], promotion of wound healing [60] and angiogenesis [61], and modulation of cell death $[62,63]$.

\section{Antiviral Activity of $\alpha$-Defensins}

Although the field of antimicrobial peptide research has been dominated by evaluation of the antibacterial activities of these peptides, early studies evaluating the antiviral potential of human $\boldsymbol{\alpha}$-defensins showed promise and have been followed by an increasing level of research interest (Fig. 1).

\subsection{Herpes Simplex Virus}

The first paper detailing an antiviral role was published 27 years ago, describing inhibition of a number of viruses including HSV types 1 and 2, cytomegalovirus and vesicular stomatitis virus by HNP1 in vitro [64]. In particular, it demonstrated direct antiviral activity of HNP1 against HSV-1 in a temperature- and pH-dependent manner, inhibited by serum, but interestingly less sensitive to the inhibitory effects of cations than the more broadly studied antibacterial properties.

HNP1-4, HD5 and HD6 have subsequently been found to be active against HSV-2 (up to approximately $1 \mathrm{log}$ decrease at $50 \mu \mathrm{g} / \mathrm{ml}$ ) by preventing viral binding to either glycoprotein B (gB2) or heparan sulphate (the primary receptor for $\mathrm{HSV}$ ) [65]. gB2 binding capacity was found to be primarily determined by peptide sequence rather than net cationic charge [66], with lectin-like properties likely to be key to the glycoprotein binding functions [67]. Interestingly, those defensins (HNP1-3 and HBD5) which bound viral envelope $\mathrm{gB}$ were also found to be effective at preventing infection if added after viral entry, even up to $8 \mathrm{~h}$ post-infection (with HNP1 or HD5), suggesting additional later stage effects on viral replication [65]. Furthermore, cumulative effects were observed with repeated application of peptide, reducing infection with HSV by greater than $7 \operatorname{logs}$ at $100 \mu \mathrm{g} / \mathrm{ml}$. These features make $\alpha$-defensins of considerable interest as potential exogenous vaginal microbicides, with a proof of concept study in mice demonstrating protection against HSV following gel-based application of HD5 [65].

\subsection{HIV-1}

$\alpha$-Defensins have been demonstrated to directly inactivate HIV-1, with the observation of reduced cytopathogenicity in a $\mathrm{CD}^{+} \mathrm{T}$ cell line [68]. Although confusion existed following the retraction of a paper proposing that $\alpha$ defensins were the key component of the CD8 antiviral factor CAF [69, 70], it is worth noting that the retraction related to the source of the $\alpha$-defensins (probably "imported" into CD8 cells from co-cultured cells), and the anti-HIV-1 properties of the peptides were not called into question. Indeed, the potential of $\alpha$-defensins to treat HIV was reinforced when it was found that breast milk $\alpha$-defensin concentration is significantly associated with a decreased risk of intrapartum and postnatal HIV transmission [71].

Recent studies demonstrate that multiple steps in the entry of HIV-1 virus into cells are disrupted by HNP1 [72]. This peptide has been shown to bind to CD4 and to the env glycoprotein on the virus, thus inducing the down-regulation of CD4 and CXCR4 and blocking interaction of env 
Fig. 1 Antiviral activities of $\alpha$ defensins. $\alpha$-Defensins have antiviral activity against herpes simplex virus (HSV), human immunodeficiency virus (HIV), influenza A virus (IAV), human papillomavirus (HPV) and adenovirus (Adv), via a range of different mechanisms

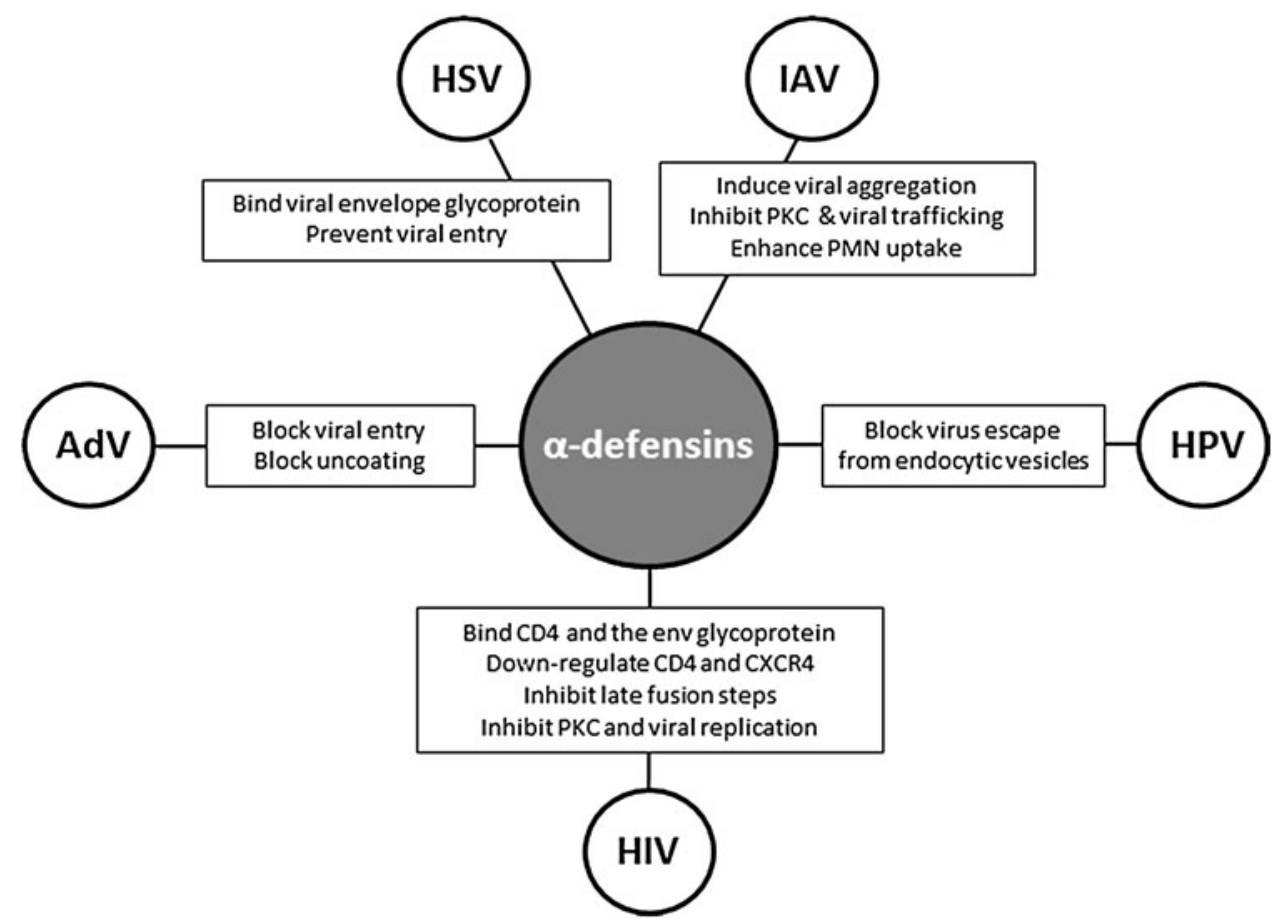

with the co-receptors. By targeting particular conformations of env it also inhibited late fusion steps [72]. HNP1-3 can bind to CD4 and HIV-1 gp120 with high affinity; however, HNP4, which is a much weaker binder, is a more potent inhibitor, meaning this aspect of direct inhibition is not, currently, entirely clear [73]. Mechanistic studies have shown that HNP1-3 can also inhibit steps following reverse transcription and integration by inhibiting PKC activity; PKC is important for HIV replication as it upregulates transcription through $\mathrm{NF}-\kappa \mathrm{B}$ activation and Tat phosphorylation, as well as regulating fusion and assembly of the virions [74]. It is worth noting that in these studies the direct effects on the virus particles occurred only in the absence of serum; in its presence, these mechanisms were inhibited and effects are instead on the host cells, resulting in inhibited replication of the virus [69, 74-76]. Defensins can also stimulate an antiviral state in cells by promoting secretion of chemokines [76]. In macrophages this upregulation of chemokines also contributes to inhibition of HIV through competition for receptors [76].

A potential issue with using defensins as a topical antiviral treatment is that, despite CHDPs (including defensins) being required for in vitro anti-HIV activity of vaginal fluid from healthy women, defensins may also cause immune activation and subsequent loss of $\mathrm{CD} 4^{+} \mathrm{T}$ cells by apoptosis, and may indirectly enhance HIV transmission [77]. In particular, it is known that HNP2 and HBD2 are both chemotactic for DC and induce infiltration of DC into cultures of HPV-transformed keratinocytes and subsequent immune activation [78]. In addition, HD5 and
6, which are produced by cervico-vaginal epithelial cells [18] and present at up to $50 \mu \mathrm{g} / \mathrm{ml}$ in the vaginal fluid of healthy women [79], enhance HIV infectivity in vitro by promoting the virus attachment to target cells [18, 79]. Thus, the balance of these effects remains to be determined.

\subsection{Influenza A Virus}

$\alpha$-Defensins are also found in high concentrations in the inflamed lung, generating interest in their potential activities against respiratory viruses. HNP1-3 are the most abundant antimicrobial peptides in airway fluid [80] and are up-regulated further following infection or inflammation [81] as they are produced by both immigrating neutrophils and airway epithelial cells [82].

Daher et al. [64] first described antiviral effects of HNP1 against the WSN strain of IAV in vitro, showing a fairly modest approximately $0.5 \mathrm{log}$ reduction at $50 \mu \mathrm{g} / \mathrm{ml}$. This property of HNP1 and 2 was later confirmed in other strains of IAV (with decreased infectivity of approximately $1 \log$ at $10 \mu \mathrm{g} / \mathrm{ml}$ in a fluorescent focus assay of infectivity). The peptides were shown to have no activity in a haemagglutinin inhibition assay [83], but to induce aggregation of IAV [84]. Interestingly HNP aggregation of the PR8 viral strain was much higher than that of the Phil82 strain, which has greater surface glycosylation [84-86], and neutralising activity of HNPs was greater against PR8 than against Phil82 [83], suggesting the reduced carbohydrate attachments on the envelope proteins allow greater 
interaction with the defensins. However, direct effects of HNP1 on IAV viral particles were found to have no impact on viral growth in infected cultures [87]. Maximal antiviral effects in this study $(1-3 \operatorname{logs}$ at $5-25 \mu \mathrm{g} / \mathrm{ml} \mathrm{HNP1}$ in a range of cell lines) required interaction of HNP1 with the eukaryotic cells before infection and the continued presence of peptide in the culture system. Nevertheless, in contrast to pretreatment of virus, pretreatment of the cells did induce some protection.

This suggests the predominant mechanism of action is cell-mediated, and has been proposed to be a consequence of HNP-mediated inhibition of PKC activity (essential for endosomal trafficking of the IAV) [87, 88]. The capacity of $\alpha$-defensin to protect against IAV was lost in its linearised analogue [87]. In addition to effects on IAV infection of epithelial cells, HNP1 and 2 at approximately $40 \mu \mathrm{g} / \mathrm{ml}$ (but not HNP3, HBD2 or 3) can enhance the uptake of IAV by neutrophils, following pre-incubation of either the cells or the virus with the defensins [84]. However, this modulation of neutrophil phagocytic capacity was also observed using bacteria, and was not virus specific.

These properties of $\alpha$-defensins suggest potential as templates for novel therapeutics. However, their ability to bind surfactant protein D (SP-D) may be of concern, having mixed competitive or co-operative, and IAV straindependent effects on the antiviral activities of SP-D [83]. HNPs (but not $\beta$-defensins) can bind and precipitate bronchoalveolar lavage (BAL) fluid SP-D [83, 89] and may account for SP-D depletion from the lung in diseases with chronic neutrophilic inflammation.

\subsection{Non-Enveloped Viruses}

It was originally suggested that $\alpha$-defensins had no activity against non-enveloped viruses, on the basis of the absence of effects against echovirus type II and reovirus type 3 [64]. However, more recent work has demonstrated inhibition of non-enveloped viruses such as adenovirus, human papillomavirus (HPV) [90-92] and BK virus [93].

The mechanisms underpinning these antiviral effects against non-enveloped viruses appear to be distinct from those targeting enveloped viruses. A study of HPV (utilising pseudovirus particles) found normal binding, uncoating and internalisation in the presence of $\alpha$-defensins; however, the peptides prevented the virion from escaping the endocytic vesicles [92]. The antiviral activity was observed using HNP1-4 (and the cathelicidin LL-37), was maximal using HD5, but was not observed using HD6.

The sensitivity of adenoviruses to $\alpha$-defensin-mediated neutralisation is serotype-dependent [90, 94]. HNP1 and HD5 have been shown to inhibit human adenovirus infection in both lung and conjunctival epithelial cells by inhibiting an early step in viral entry $[90,91,95,96]$. Two arginine residues on one face of HD5 were found to be critical for antiviral activity, with Arg-28 necessary for killing of both AdV and HPV and Arg-9 for AdV only [97]. Viral aggregation is not sufficient for neutralisation and binding of $\alpha$-defensin to the adenoviral virus capsid appears to be critical, preventing uncoating in the cell and hence entry of the viral genome into the nucleus [97, 98]. In contrast, the antiviral effects of HNP1 and HD5 on the BK polyomavirus appear to primarily relate to viral aggregation preventing receptor binding on the host cells [93].

\section{Antiviral Activity of $\beta$-Defensins}

$\beta$-Defensins can be induced in both humans and mice following viral infection. $\mathrm{mBD} 3$ and 4 (orthologues of HBD2) are murine $\beta$-defensins which are induced in vivo during influenza virus (IAV) infection in mice [99], whereas HIV-1 infection induced HBD2 and 3 expression in normal human oral epithelium, even if the virus was not replicating [100]. Similarly, human rhinovirus (HRV) replication in human bronchial epithelial cells induces NF$\kappa \mathrm{B}$-dependent HBD2 and 3 expression (but not HBD1) [101, 102], whereas respiratory syncytial virus (RSV) can induce HBD2 in an NF- $\mathrm{KB}$-dependent, but IFN type 1 -independent manner in human lung epithelial cells [103]. The extent to which these innate responses are functionally effective against the viral pathogens is starting to be elucidated (Fig. 2).

\subsection{Herpes Simplex Virus}

In contrast to the effects of $\alpha$-defensins, only one of the $\beta$ defensins tested (HBD3) had appreciable effects against HSV [65]. HBD3 was found to inhibit HSV-2 infection of human cervical epithelial cells (by approximately $1 \log$ at $10 \mu \mathrm{g} / \mathrm{ml}$ ) by interfering with the viral binding and penetration processes by binding both $\mathrm{gB}$ and heparan sulphate. In contrast, HBD1 and HBD2 had low affinity to $\mathrm{gB}$ and cellular glycosaminoglycans, and were not able to reduce HSV-2 infectivity. However, only HD5 was applied in vivo in this study [65].

\subsection{HIV-1}

HIV-1 infection of epithelial cells induces HBD2 and 3 expression in vitro [100] and in buccal mucosal cells in vivo [104], and both inhibit HIV transmission through multiple mechanisms [100, 105]. Both down-regulate the co-receptor CXCR4 expression (but not CCR5) on the surface of $\mathrm{CD}^{+}{ }^{+} \mathrm{T}$ cells via an increase in internalisation [106]. In addition, there are both direct effects on the 
Fig. 2 Antiviral activities of $\beta$ defensins. $\beta$-Defensins have antiviral activity against herpes simplex virus (HSV), human immunodeficiency virus (HIV), influenza A virus (IAV), respiratory syncytial virus (RSV) and vaccinia virus (VV), via a range of different mechanisms

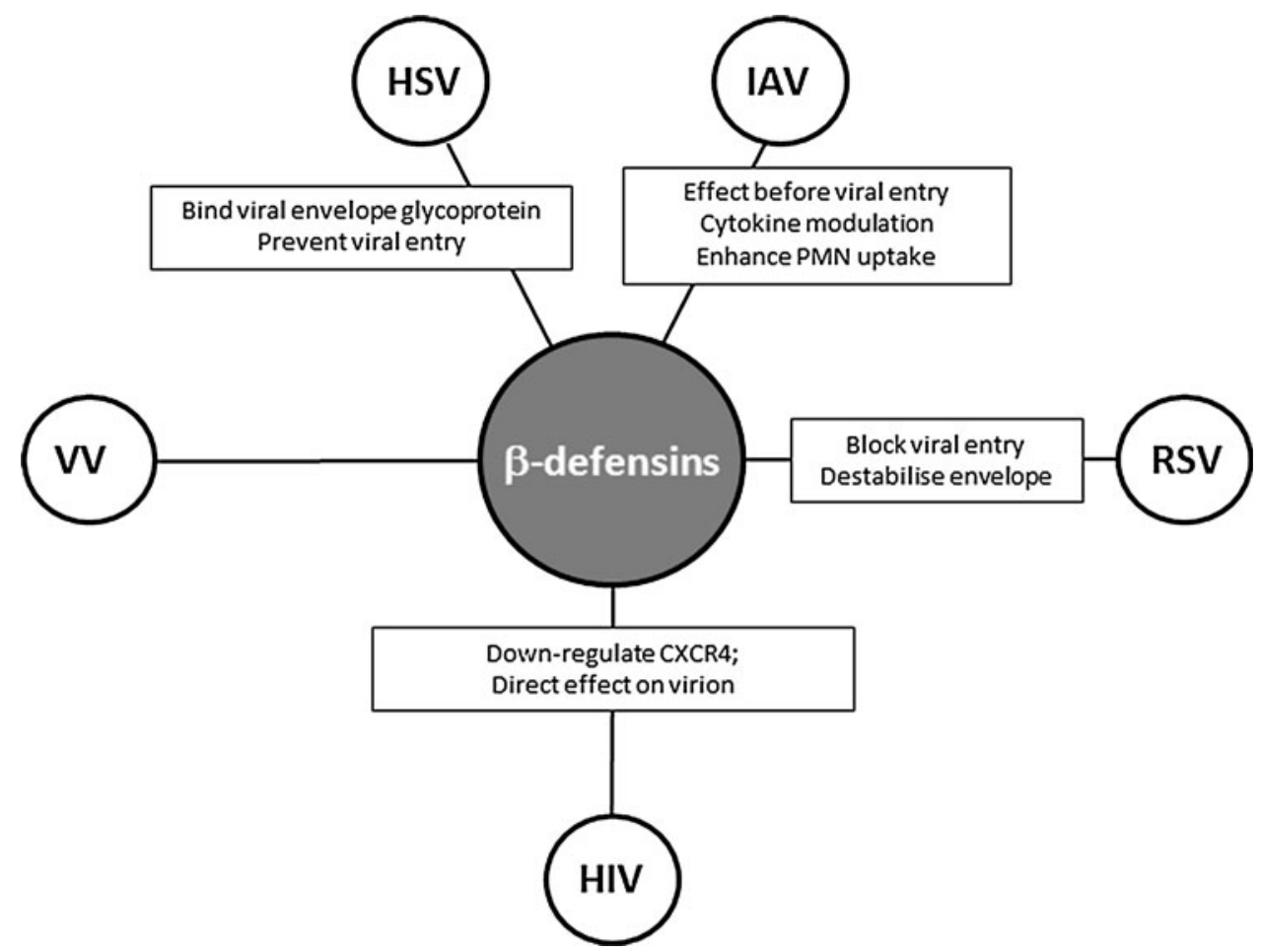

virions in a concentration-dependent manner [100] and on intracellular, post-viral entry inhibition [105].

However, in large-scale studies, copy number variation of total $\beta$-defensin gene number positively correlates with HIV load in Ethiopian and Tanzanian patients [107]. The authors suggest that the chemoattractant nature of $\beta$ defensins may bring the target Th17 cells into mucosal sites where they can be readily infected by virus. Other work, however, has recently shown that exposed but seronegative individuals have much higher HBD2 and 3 copy numbers in oral mucosa (but not vaginal mucosa) than healthy controls, indicating a role for these defensins in combating infection [108].

\subsection{Influenza A Virus}

Although not normally regarded as inducible, expression of HBD1 (but not HBD2, 3 or 4) has been observed in primary human blood-derived plasmacytoid DC and monocytes following infection with IAV [109]. In contrast, an early decrease in expression of this peptide was found in IAV-infected epithelial cell lines [109]. Recombinant HBD1 was found to have antiviral effects in vitro (approximately $1.5 \mathrm{log}$ decrease at $50 \mu \mathrm{g} / \mathrm{ml}$ ). However, despite evidence of a significant defect in host defence against IAV in Defbl-deficient mice, this did not extend to differences in viral load, suggesting a primary role of immunomodulatory properties in vivo [109]. IAV has been found to up-regulate expression of murine defensins mBD3 and mBD4 in upper and lower airways, as well as transcription of the genes encoding $\mathrm{mBD} 1$ and $\mathrm{mBD} 2$ in the lung [99], also suggesting protective roles for these peptides. Recombinant mBD2 [110] and mBD3 [111] protected MDCK cells against infection with IAV PR8 strain (up to approximately $1 \log$ decrease at $100 \mu \mathrm{g} / \mathrm{ml}$ ); this protection was effective during binding or internalisation of the virus, but not after viral entry. Furthermore, repeated intranasal administration of recombinant $\mathrm{mBD} 2(2 \mathrm{mg} / \mathrm{kg}$; optimal when premixed with virus before infection) or intravenous delivery of recombinant $\mathrm{mBD} 3(10 \mathrm{mg} / \mathrm{kg})$ was found to be protective in murine lethal infection models $[110,111]$. The latter study also suggested that the effects may relate to immunomodulatory properties, with systemic mBD3 treatment up-regulating IFN- $\gamma$ and IL-12 and reducing levels of TNF. Thus, although $\beta$-defensins can inhibit influenza virus infectivity (albeit less potently than the $\alpha$-defensins or LL-37) [89], immunomodulatory properties, perhaps also including up-regulation of IAV uptake by neutrophils [84], may prove to be key to their protective function against this virus in vivo and future therapeutic developments.

\subsection{Respiratory Syncytial Virus}

In addition to effects on IAV, evidence has been found for $\beta$-defensin activity against RSV, another important respiratory virus, for which no effective vaccine or antiviral treatments exist. In studies using the A549 human lung cell 
line, HBD2 was identified as a component of an NF- $\mathrm{KB}-$ dependent, IFN- $\alpha / \beta$-independent antiviral response [103]. Epithelial cell HBD2 production was induced in response to RSV replication and also in response to the TNF secreted by infected epithelial cells. HBD2, but not HBD1, was found to protect against RSV infection (approximately $2 \log$ decrease at $4 \mu \mathrm{g} / \mathrm{ml}$ ), by blocking viral cellular entry [103]. Destabilisation of the viral envelope was proposed to occur upon contact with soluble HBD2 in solution, or following exposure to plasma membrane-associated HBD2 during cell entry. In addition to lung epithelial cells, myeloid cells can produce high levels of TNF in response to RSV infection [112]. This has the potential to up-regulate HBD2 expression in the airway lumen and might consequently modulate protection against RSV infection and limit virus spread. Interestingly mBD4 (but not mBD3; both considered homologues to HBD2) was found to be upregulated in vivo in the murine lung in response to RSV infection [103].

\subsection{Vaccinia Virus}

HBD3 has been proposed to have antiviral activity against vaccinia virus [113]. However, HNP1, HBD1 and HBD2 are unable to neutralise the virus [114]. Pre-exposure of virus to synthetic HBD3 for $24 \mathrm{~h}$ decreased infection of the BSC-1 monkey kidney cell line, shown both by reduced levels of DNA-dependent RNA polymerase expression and plaque formation (approximately $1 \log$ decrease at $10 \mu \mathrm{M}$ ) [113], although the mechanism remains to be elucidated. Up-regulation of HBD3 expression was observed in response to vaccinia virus infection in primary human keratinocytes, but this could be inhibited by IL-4 and IL-13 . Interestingly, these cytokines are associated with pathology in atopic dermatitis, a condition in which $\beta$-defensin expression is reduced [115] and patients are at risk of developing eczema vaccinatum caused by vaccinia virus.

\section{Antiviral Activity of $\theta$-Defensins}

Circular $\theta$-defensins were identified in the leukocytes and bone marrow of macaques (Rhesus $\theta$-defensins; RTD) [116] and discovered to have effective antibacterial activity. Humans were found to have at least six $\theta$-defensin genes (DEFT genes) [117], but none produce a translated protein, owing to insertion of a premature stop codon. Putative ancestral human $\theta$-defensins, named retrocyclins (RC), were developed and their antimicrobial properties were tested [117]. In addition to activity against Pseudomonas aeruginosa, E. coli, Listeria monocytogenes and Staphylococcus aureus, antiviral potential has also been described (Fig. 3).

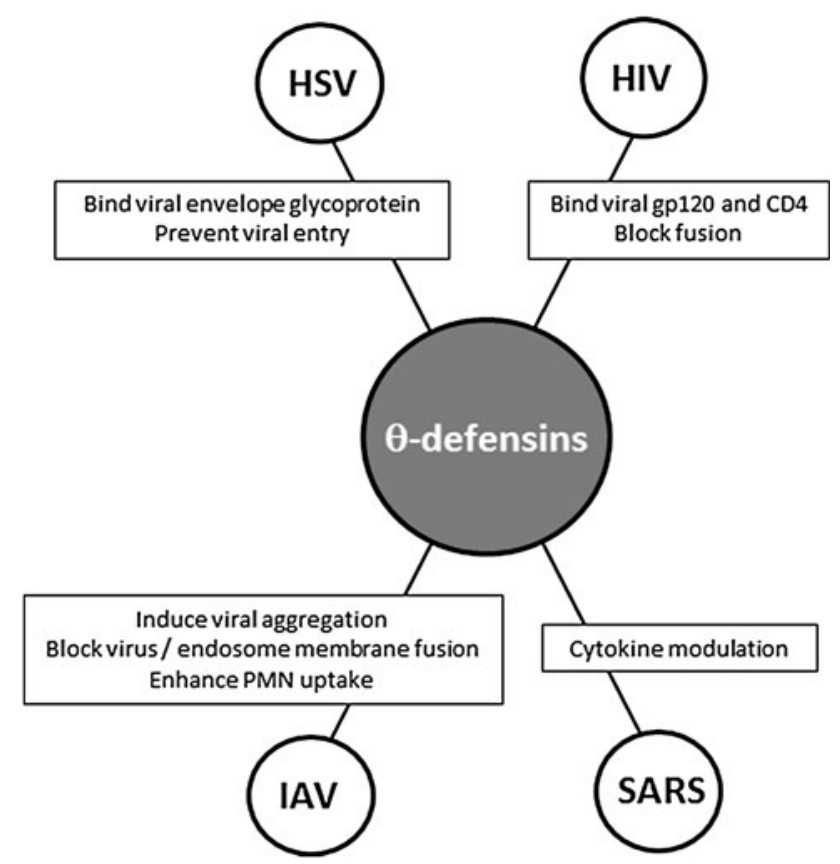

Fig. 3 Antiviral activities of $\theta$-defensins. $\theta$-Defensins have antiviral activity against herpes simplex virus (HSV), human immunodeficiency virus (HIV), influenza A virus (IAV), SARS coronavirus (SARS), via a range of different mechanisms

\subsection{Herpes Simplex Virus}

Both rhesus $\theta$-defensins and retrocyclins (including RTD3, $\mathrm{RC} 1$ and $\mathrm{RC} 2$ ) have been found to inhibit HSV-1 and HSV-2 infection of human cervical epithelial cell lines following pre-incubation of virus and peptide [66]. However, RC2 was found to have no direct virucidal properties [118], but to be active irrespective of pre-incubation by blocking attachment and cell penetration of HSV [66]. This activity resulted from peptide binding to $\mathrm{gB} 2$, in a manner dependent on the presence of sialic acid and carbohydrate moieties in the glycoprotein's $O$ - and $N$-linked glycans. Prophylactic application of RC2 in a murine HSV-mediated ocular keratitis model demonstrated the capacity of $\mathrm{RC} 2$ to modestly reduce viral titres in vivo and reduce blepharitis, corneal vascularization and stromal disease. However, RC2 had no effect upon disease pathology when applied post-infection [118].

\subsection{HIV-1}

Initial studies on retrocyclins found no direct inactivation of HIV-1, but demonstrated strong inhibition of proviral DNA formation and protection of primary human $\mathrm{CD} 4^{+} \mathrm{T}$ cells from T- and M-tropic HIV-1 strains in vitro [117, 119]. These observations led to a significant body of work evaluating retrocyclins as HIV treatments. RC1 has been characterised as a lectin, which protects peripheral blood 
leukocytes from HIV-1 [117]. This peptide prevents viral entry into cells $[42,119]$, blocking formation of the 6-helix bundle required for fusion, by binding to HIV gp120 and cellular CD4 through interactions with their $\mathrm{O}$ - and $\mathrm{N}$ linked sugars [120].

Activity of many of the initial retrocyclins produced was inhibited by serum, minimising usefulness in serum-containing anatomical compartments [42]. However, analogues, each differing from $\mathrm{RC} 1$ by a single amino acid substitution, show greater potential as topical microbicides [121]. Of these, RC100 was found to inhibit primary CD4 ${ }^{+}$ $\mathrm{T}$ cell infection by HIV-1 similarly to RC1, but was active in the presence of vaginal fluid, and RC101 is significantly more potent against $\mathrm{HIV}$ than $\mathrm{RC} 1$; both have potential as topical microbicides [122]. Interestingly, the rate of escape mutations of RC100-treated HIV was low; treatment altered sites in HR1 and HR2 of gp410 but these only reduced susceptibility by 10-fold, compared to 10,000-20,000-fold for CCR5 blockade [122]. Using an organ culture model, RC101 was found to block transmission of two strains of HIV-1 across cervical mucosa. Antiviral activity was retained in the presence of semen and vaginal fluid, there was no cytotoxicity to cervical tissue and, importantly, RC101 did not induce a pro-inflammatory response, with no chemotactic activity for immune cells [123]. In addition, topical intra-vaginal RC101 application in pigtailed macaques was found to be safe and well tolerated, with peptide retained in the cervical and vaginal tissue for up to 4 days post-application, no changes in vaginal $\mathrm{pH}$ observed and minimal effects on commensal microbiota [124].

\subsection{Respiratory Viruses}

The application of retrocyclins to pathogenic respiratory viruses has also been evaluated. Expression of recombinant RC2 in both MDCK cells and chicken embryos has been shown to inhibit replication of an H5N1 influenza virus [125]. In addition, RC1, RC2 and RC101 all had antiviral activities in studies using MDCK and A549 cell lines (approximately $1 \log$ decrease at $20 \mu \mathrm{g} / \mathrm{ml}$ against IAV Phil82, but less effective against PR8 strain) [89]. The retrocyclins were more effective than HBD1 and HBD2, with potency equivalent to HNP1-3. This study noted the capacity of the RC peptides to induce aggregation of the virus and increase viral uptake by neutrophils and macrophages [89]. RC2 was also found to inhibit influenza $\mathrm{A} / \mathrm{X} 31$ infection of cell lines in vitro by blocking the haemagglutinin-mediated fusion of viral and endosomal membranes [85]. The inhibition of hemifusion formation was shown to be a lectin property which involved cross linking and immobilising surface glycoproteins and blocking the protein displacement required to bridge the bilayers for fusion. RC2 was only effective when given before viral internalisation, but had antiviral properties even when only applied to the host cell membrane.

Interestingly, despite the capacity to bind SP-D, retrocyclins increased, rather than inhibited, the antiviral activity of SP-D [89]. This is in contrast to the $\alpha$-defensins [83], and promising for therapeutic use at mucosal sites.

To further improve the antiviral activity of synthetic retrocyclins against influenza and simplify their structure, a series of analogues containing 13-14 amino acids, termed hapivirins and diprovirins, were designed [126]. Some of these analogues, including $\mathrm{HpV} 1,8,11-15,17,19$ and DpV 13, 16, 1623 and 1632 proved to be more effective than RC2 and RC101 against IAV Phil82 (H3N2) and PR-8 (H1N1). Mechanistically analogous to the retrocyclins, these peptides were found to be active before viral internalisation, induce viral aggregation, opsonise virus, and have an additive effect with SP-D. In addition, hapivirins and diprovirins were shown to inhibit IAV-induced macrophage TNF production, adding immunomodulatory mechanism to their therapeutic potential.

Antiviral activity of retrocyclins has also been reported against SARS virus, a coronavirus which infects the alveolar epithelial cells and induces rapid severe lung pathology $[127,128]$. In a mouse model of SARS infection, RTD-1 treatment increased survival from 25 to $100 \%$. Interestingly, this was in the absence of any impact on viral titres. Instead the cytokine profile of the infected animals was modified, with increased early (day 2) production of IL-6 and GM-CSF, but decreased IL- $1 \alpha$, IL-1 $\beta$, IL-6, MIP1 $\alpha$, and IL-12p40 by day 4 . These data highlight the possibility that novel peptide therapeutics may be productively targeted at modulation of the inflammatory response to infection, rather than developed for virucidal properties per se. Such an approach may prove to have broad-spectrum applicability and lends further support to the potential for these peptides as novel immunomodulatory antiviral agents.

\section{Antiviral Activity of Cathelicidins}

Cathelicidins have been widely studied with regard to their antibacterial properties and broad array of immunomodulatory activities [6]. Although known to be up-regulated in inflammation and released by neutrophils, their roles in defence against viral infection and properties as antiviral agents are less well understood (Fig. 4).

\subsection{HIV-1}

hCAP-18 is expressed in human epididymal epithelium and is present at high concentrations in seminal plasma [129]. It 


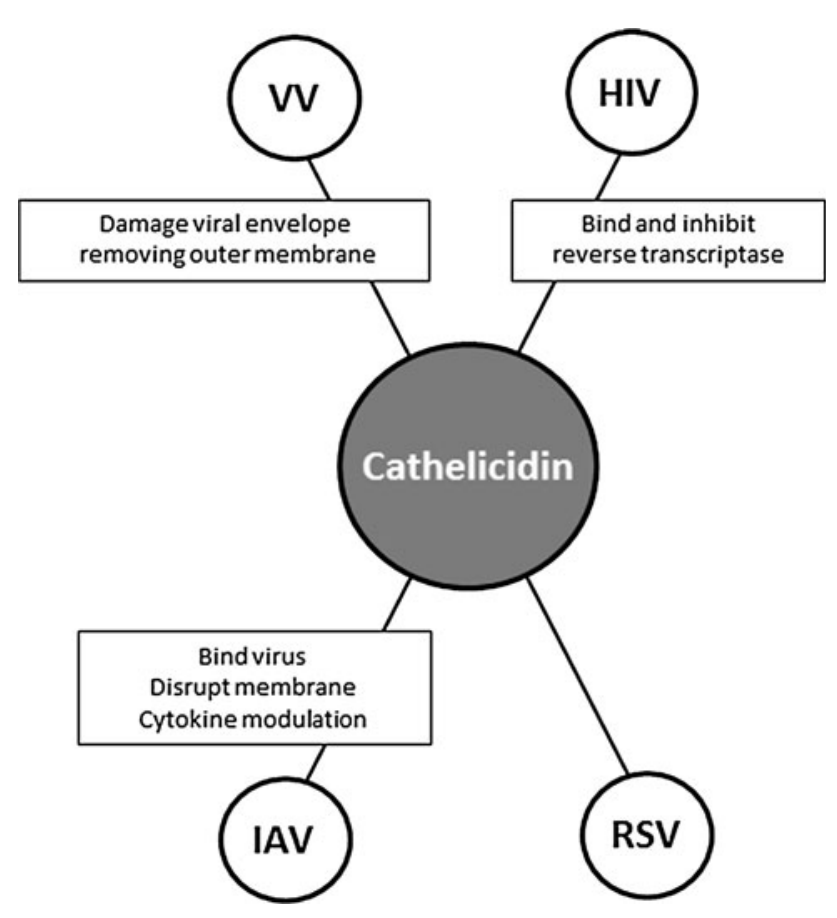

Fig. 4 Antiviral activities of cathelicidins. Cathelicidins have antiviral activity against human immunodeficiency virus (HIV), influenza A virus (IAV), respiratory syncytial virus (RSV) and vaccinia virus $(\mathrm{VV})$, via a range of different mechanisms

is also expressed in cervico-vaginal secretions and upregulated in participants with bacterial sexually transmitted infections [130]. Cervico-vaginal LL-37 levels in HIVnegative individuals who were in HIV sero-discordant relationships were also found to be greatest in those whose HIV-positive partners had the highest viral load [131]. LL37 has been shown to inhibit the replication of a range of HIV-1 isolates in primary $\mathrm{CD}^{+} \mathrm{T}$ cells [132]. This occurred in a manner that was independent of change in expression of any HIV-1 receptors in these cells. A recent study demonstrated that LL-37 was capable of a dosedependent suppression of HIV reverse transcriptase activity [133]. This study also demonstrated that this function was retained by a 16 amino acid fragment of LL-37 (17-32), with implications for production of smaller synthetic analogues. Thus, epithelial expression of LL-37 has been proposed to contribute to local protection against HIV-1 infection. However, although the cationic peptide fraction of cervico-vaginal secretions was found to have HIV-1neutralising activity, which could be enhanced by addition of recombinant LL-37, this property did not correlate with levels of endogenous LL-37 detected [131]. In addition, in one study LL-37 levels were independently associated with increased HIV acquisition, although both observations might be the result of a high prevalence of sexually transmitted infections in these individuals [130]. Therefore, the in vivo significance of LL-37 in HIV remains unclear.

\subsection{Influenza A Virus}

We recently demonstrated that LL-37 has antiviral effects against IAV, both in vitro and in vivo [134]. Both human and murine cathelicidins had antiviral activity when preincubated with influenza viruses in vitro [approximately $1 \log$ decrease at $10 \mu \mathrm{g} / \mathrm{ml}$ against A/PR/8/34 (H1N1), but somewhat less effective against A/Udorn/307/72 (H3N2)]. In addition, LL-37 has recently been shown to bind IAV, without aggregating or affecting haemagglutination activity, and to have maximal effects in vitro when pre-incubated with virus (although delayed addition of peptide or treatment of the cells, with washing before infection also has some antiviral effects) [135]. Surprisingly, LL-37 was found not to alter the binding or initial uptake of virus by cells, but peptide-mediated disruption of viral membranes (shown by electron microscopy) was proposed to affect viral propagation or survival downstream of this [135].

We demonstrated that aerosolised therapeutic administration of either LL-37 or mCRAMP (given every day for 1 week, with an additional pre-infection dose) provided protection against infection in a mouse model [134]. Peptide-treated mice showed increased survival and decreased weight loss compared to control infected animals, and were similarly protected to those treated with zanamavir (a neuraminidase inhibitor currently used therapeutically in humans). The cathelicidin-treated mice showed some decrease in viral loads, but more striking reductions in lung cytokines (in particular GM-CSF, IL$1 \beta, \mathrm{KC}$ and CCL5), again suggesting the possibility of a key immunomodulatory roles in the antiviral efficacy of such peptides. Scrambled control peptides did not have these effects but interestingly the D-enantiomers did, indicating the actions of LL-37 are not solely related to charge and are likely not reliant on specific receptor interactions.

The mechanisms by which cathelicidins modulate inflammation in IAV infection remain unclear, but may relate to the observation that LL-37 can modulate Tolllike receptor signalling [136]. Induction of rapid antiviral responses depends, at least in part, on TLR recognition of the viral genome, with ssRNA and dsRNA viruses recognised by TLR7/8 and TLR3 [137]. LL-37 complexed with self DNA and RNA has been shown to induce TLR7-, TLR8- and TLR9-dependent inflammatory responses to otherwise non-immunostimulatory nucleic acids [59, 138]. In addition, LL-37 has been proposed to enhance [139, 140] or inhibit [141] TLR3-dependent responses to viral RNA or synthetic mimics. These modulatory properties may well prove to underpin the in vivo effects. 


\subsection{Respiratory Syncytial Virus}

The expression of LL-37/hCAP18 by airway epithelial cells can be induced in vitro by infection with RSV [142], in a manner that is significantly enhanced by the $1,25 \mathrm{OH}$ metabolite of vitamin D. In addition, a recent study found that median serum hCAP-18 levels are significantly lower in children with RSV bronchiolitis than in children with bronchiolitis caused by human rhinovirus [143]. Furthermore, RSV-infected children with hCAP-18 levels lower than the median are more likely to be hospitalised for prolonged periods than those with hCAP-18 levels above the median. These findings suggest an important antiviral role for LL-37 in host innate immune response against RSV. In keeping with this hypothesis, we have recently demonstrated that LL-37 exhibits effective, dose-dependent and timing-specific anti-RSV activity in vitro in a number of cell lines [144]. These data indicate that therapeutic use of cathelicidin or strategies to up-regulate cathelicidin expression in vivo (particularly during the winter when low vitamin D levels may lead to diminished cathelicidin expression) may be protective against RSV infections.

\subsection{Vaccinia Virus}

Individuals with atopic dermatitis (AD) have low levels of LL-37 expression and increased susceptibility to skin infections, in contrast to those with psoriasis, who have high levels of LL-37 expression and are less prone to skin infections, despite similar disruption to skin barrier function [145]. The low levels of LL-37 expression in AD are proposed to be important in the susceptibility to eczema vaccinatum, a disseminated viral skin infection that follows inoculation with vaccinia virus (VV). LL-37 expression was induced in response to $\mathrm{VV}$ in normal and psoriatic skin biopsies, but not those from AD skin [146]. Both LL-37 and mCRAMP have been shown to have antiviral activity against vaccinia virus in vitro (approximately $1 \log$ decrease at $25 \mu \mathrm{M}$ ) [114]. These peptides were shown to damage the integrity of the double-layered viral envelope [114], by removing the outer membrane [147]. In addition, Camp-/- mice were found to develop significantly more pox skin lesions following infection with $\mathrm{VV}$, demonstrating the antiviral effects of cathelicidins in vivo [114]. Interestingly these effects against VV were found to be specific to cathelicidins, with HNP1, HBD1 and HBD2 unable to neutralise the virus [114]. This implies that the different CHDPs may have different (if sometimes overlapping) targets in order to successfully deal with the enormously wide range of human pathogens.

\section{Conclusion}

The antiviral activities of host defence peptides have been somewhat neglected until recently, in contrast to the study of their antibacterial effects. Yet, as discussed in this review, a strong basis exists for future evaluation of the physiological roles of CHDPs as key components of innate antiviral host defences and to develop synthetic analogues as novel antiviral therapeutics. The precise mechanisms involved clearly vary in a peptide- and virus-specific manner, from direct effects on the viruses through to primarily immunomodulatory properties. These need to be examined in detail and tested in vivo against specific viral infections. Such research is expected to reveal therapeutic strategies that range from simple administration of more potent antiviral and/or immunomodulatory analogues, to therapeutic measures to enhance natural levels of expression, replace down-regulated peptides or provide peptide at an earlier, critical "tipping point" stage in infection. Although some peptides may prove to be effective when administered after infection is established, the optimal use of other peptide therapeutics may be prophylactic administration in high-risk populations (e.g. infants and elderly in an outbreak of a novel influenza strain for which a vaccine is not available).

Challenges remain in optimising peptide therapeutics to develop the shortest, cheapest analogues that are stable and function at lower concentrations, in physiological environments, without cytotoxic effects or the generation of resistance. In this regard, the $\theta$-defensins appear particularly exciting as potential topical anti-HIV agents. They are well tolerated, certain members of the family appear to function in the presence of serum, they rapidly and directly kill HIV-1 without inducing large-scale immune activation and escape variants are infrequent.

Engineering of peptides is a simple process, which enables development of more suitable compounds. The difference in the antiviral capabilities and $\mathrm{RC}_{50}$ values of HNP1 and 3, despite them differing by only a single amino acid, hints at what is possible. The engineering of RC101 from RC1 (again a single amino acid change) leading to significantly higher anti-HIV-1 activity also suggests that further enhancements should be possible. Likewise, linear, disulphide bond-free defensins have been generated [148], which retain potent antimicrobial activity. The development of linear peptides would be significantly easier than recreating their tertiary structure. However, the stability of such peptides against protease degradation remains uncertain and loss of antiviral properties following linearisation has been described in some instances [18, 94], highlighting the need for further research. Thus, in an era of increasing concern about the resurgent threats of infectious diseases, 
a very limited repertoire of antiviral drugs and fears about the rapidity with which new viruses can spread globally, peptide therapeutics have potential that is clearly worth pursuing.

Acknowledgments DJD is supported by a MRC Senior Non-clinical Research Fellowship (G1002046). SMC is supported by a University of Edinburgh College of Medicine and Veterinary Medicine Studentship. The authors have no conflicts of interest that are directly relevant to the content of this article.

Open Access This article is distributed under the terms of the Creative Commons Attribution Noncommercial License which permits any noncommercial use, distribution, and reproduction in any medium, provided the original author(s) and the source are credited. The exclusive right to any commercial use of the article is with Springer.

\section{References}

1. Liu L, Johnson HL, Cousens S, Perin J, Scott S, Lawn JE, et al. Global, regional, and national causes of child mortality: an updated systematic analysis for 2010 with time trends since 2000. Lancet. 2012;379(9832):2151-61.

2. De Clerq E. Antivirals: current state of the art. Future Virol. 2008;3(4):393-405

3. Thakur N, Qureshi A, Kumar M. AVPpred: collection and prediction of highly effective antiviral peptides. Nucleic Acids Res. 2012;40(Web Server issue):W199-204.

4. Choi KY, Chow LN, Mookherjee N. Cationic host defence peptides: multifaceted role in immune modulation and inflammation. J Innate Immun. 2012;4(4):361-70.

5. Bowdish DM, Davidson DJ, Hancock RE. A re-evaluation of the role of host defence peptides in mammalian immunity. Curr Protein Pept Sci. 2005;6(1):35-51.

6. Beaumont PE, Li H, Davidson DJ. LL-37: an immunomodulatory antimicrobial host defence peptide. In: Zaat SAJ, Hiemstra PS, editors. Antimicrobial peptides and innate immunity. Progress in inflammation research. Basel: Springer; 2013. p. 97-122.

7. Zasloff M. Antimicrobial peptides of multicellular organisms. Nature. 2002;415(6870):389-95.

8. Ganz T, Selsted ME, Szklarek D, Harwig SS, Daher K, Bainton DF, et al. Defensins. Natural peptide antibiotics of human neutrophils. J Clin Invest. 1985;76(4):1427-35.

9. Lehrer RI, Lu W. alpha-Defensins in human innate immunity. Immunol Rev. 2012;245(1):84-112.

10. Ganz T. Defensins: antimicrobial peptides of innate immunity. Nat Rev Immunol. 2003;3(9):710-20.

11. Lehrer RI, Cole AM, Selsted ME. theta-Defensins: cyclic peptides with endless potential. J Biol Chem. 2012;287(32): 27014-9.

12. Ding J, Chou YY, Chang TL. Defensins in viral infections. J Innate Immun. 2009;1(5):413-20.

13. Rehaume LM, Hancock RE. Neutrophil-derived defensins as modulators of innate immune function. Crit Rev Immunol. 2008;28(3):185-200.

14. Tan BH, Meinken C, Bastian M, Bruns H, Legaspi A, Ochoa MT, et al. Macrophages acquire neutrophil granules for antimicrobial activity against intracellular pathogens. J Immunol. 2006;177(3):1864-71.

15. Jones DE, Bevins CL. Paneth cells of the human small intestine express an antimicrobial peptide gene. J Biol Chem. 1992; 267(32):23216-25.
16. Mallow EB, Harris A, Salzman N, Russell JP, De Berardinis RJ, Ruchelli E, et al. Human enteric defensins. Gene structure and developmental expression. J Biol Chem. 1996;271(8):4038-45.

17. Quayle AJ, Porter EM, Nussbaum AA, Wang YM, Brabec C, Yip KP, et al. Gene expression, immunolocalization, and secretion of human defensin-5 in human female reproductive tract. Am J Pathol. 1998;152(5):1247-58.

18. Klotman ME, Rapista A, Teleshova N, Micsenyi A, Jarvis GA, $\mathrm{Lu} \mathrm{W}$, et al. Neisseria gonorrhoeae-induced human defensins 5 and 6 increase HIV infectivity: role in enhanced transmission. J Immunol. 2008;180(9):6176-85.

19. Ouellette AJ, Selsted ME. Paneth cell defensins: endogenous peptide components of intestinal host defense. FASEB J. 1996;10(11):1280-9.

20. Eisenhauer PB, Lehrer RI. Mouse neutrophils lack defensins. Infect Immun. 1992;60(8):3446-7.

21. Shanahan MT, Tanabe H, Ouellette AJ. Strain-specific polymorphisms in Paneth cell alpha-defensins of C57BL/6 mice and evidence of vestigial myeloid alpha-defensin pseudogenes. Infect Immun. 2011;79(1):459-73.

22. Ericksen B, Wu Z, Lu W, Lehrer RI. Antibacterial activity and specificity of the six human $\{$ alpha $\}$-defensins. Antimicrob Agents Chemother. 2005;49(1):269-75.

23. Brogden KA. Antimicrobial peptides: pore formers or metabolic inhibitors in bacteria? Nat Rev Microbiol. 2005;3(3):238-50.

24. Territo MC, Ganz T, Selsted ME, Lehrer R. Monocyte-chemotactic activity of defensins from human neutrophils. J Clin Invest. 1989;84(6):2017-20.

25. Yang D, Chen Q, Chertov O, Oppenheim JJ. Human neutrophil defensins selectively chemoattract naive $\mathrm{T}$ and immature dendritic cells. J Leukoc Biol. 2000;68(1):9-14.

26. Miles K, Clarke DJ, Lu W, Sibinska Z, Beaumont PE, Davidson DJ, et al. Dying and necrotic neutrophils are anti-inflammatory secondary to the release of alpha-defensins. J Immunol. 2009; 183(3):2122-32.

27. Salzman NH, Hung K, Haribhai D, Chu H, Karlsson-Sjoberg J, Amir E, et al. Enteric defensins are essential regulators of intestinal microbial ecology. Nat Immunol. 2010;11(1):76-83.

28. Chu H, Pazgier M, Jung G, Nuccio SP, Castillo PA, de Jong MF, et al. Human alpha-defensin 6 promotes mucosal innate immunity through self-assembled peptide nanonets. Science. 2012;337 (6093):477-81.

29. Semple CA, Gautier P, Taylor K, Dorin JR. The changing of the guard: molecular diversity and rapid evolution of beta-defensins. Mol Divers. 2006;10(4):575-84.

30. Zhao C, Wang I, Lehrer RI. Widespread expression of betadefensin hBD-1 in human secretory glands and epithelial cells. FEBS Lett. 1996;396(2-3):319-22.

31. Duits LA, Ravensbergen B, Rademaker M, Hiemstra PS, Nibbering PH. Expression of beta-defensin 1 and 2 mRNA by human monocytes, macrophages and dendritic cells. Immunology. 2002;106(4):517-25.

32. Wehkamp J, Harder J, Wehkamp K, Wehkamp-von Meissner B, Schlee M, Enders C, et al. NF-kappaB- and AP-1-mediated induction of human beta defensin-2 in intestinal epithelial cells by Escherichia coli Nissle 1917: a novel effect of a probiotic bacterium. Infect Immun. 2004;72(10):5750-8.

33. Voss E, Wehkamp J, Wehkamp K, Stange EF, Schroder JM, Harder J. NOD2/CARD15 mediates induction of the antimicrobial peptide human beta-defensin-2. J Biol Chem. 2006; 281(4):2005-11.

34. Yang D, Biragyn A, Hoover DM, Lubkowski J, Oppenheim JJ. Multiple roles of antimicrobial defensins, cathelicidins, and eosinophil-derived neurotoxin in host defense. Annu Rev Immunol. 2004;22:181-215. 
35. Schroeder BO, Wu Z, Nuding S, Groscurth S, Marcinowski M, Beisner J, et al. Reduction of disulphide bonds unmasks potent antimicrobial activity of human beta-defensin 1. Nature. 2011;469(7330):419-23.

36. Morrison G, Kilanowski F, Davidson D, Dorin J. Characterization of the mouse Beta defensin 1, defb1, mutant mouse model. Infect Immun. 2002;70(6):3053-60.

37. Moser C, Weiner DJ, Lysenko E, Bals R, Weiser JN, Wilson $\mathrm{JM}$. beta-Defensin 1 contributes to pulmonary innate immunity in mice. Infect Immun. 2002;70(6):3068-72.

38. Yang D, Chertov O, Bykovskaia SN, Chen Q, Buffo MJ, Shogan $\mathrm{J}$, et al. Beta-defensins: linking innate and adaptive immunity through dendritic and T cell CCR6. Science. 1999;286(5439): $525-8$.

39. Hirsch T, Spielmann M, Zuhaili B, Fossum M, Metzig M, Koehler $\mathrm{T}$, et al. Human beta-defensin-3 promotes wound healing in infected diabetic wounds. J Gene Med. 2009; 11(3):220-8.

40. Semple F, Dorin JR. beta-Defensins: multifunctional modulators of infection, inflammation and more? J Innate Immun. 2012; 4(4):337-48.

41. Selsted ME, Ouellette AJ. Mammalian defensins in the antimicrobial immune response. Nat Immunol. 2005;6(6):551-7.

42. Wang W, Owen SM, Rudolph DL, Cole AM, Hong T, Waring AJ, et al. Activity of alpha- and theta-defensins against primary isolates of HIV-1. J Immunol. 2004;173(1):515-20.

43. Nguyen TX, Cole AM, Lehrer RI. Evolution of primate thetadefensins: a serpentine path to a sweet tooth. Peptides. 2003; 24(11): $1647-54$

44. Tran D, Tran P, Roberts K, Osapay G, Schaal J, Ouellette A, et al. Microbicidal properties and cytocidal selectivity of rhesus macaque theta defensins. Antimicrob Agents Chemother. 2008;52(3):944-53.

45. Zanetti M. Cathelicidins, multifunctional peptides of the innate immunity. J Leukoc Biol. 2004;75(1):39-48.

46. Sorensen O, Arnljots K, Cowland JB, Bainton DF, Borregaard $\mathrm{N}$. The human antibacterial cathelicidin, hCAP-18, is synthesized in myelocytes and metamyelocytes and localized to specific granules in neutrophils. Blood. 1997;90(7):2796-803.

47. Sorensen OE, Follin P, Johnsen AH, Calafat J, Tjabringa GS, Hiemstra PS, et al. Human cathelicidin, hCAP-18, is processed to the antimicrobial peptide LL-37 by extracellular cleavage with proteinase 3. Blood. 2001;97(12):3951-9.

48. Bowdish DM, Davidson DJ, Hancock RE. Immunomodulatory properties of defensins and cathelicidins. Curr Top Microbiol Immunol. 2006;306:27-66.

49. Frohm M, Agerberth B, Ahangari G, Stahle-Backdahl M, Liden $\mathrm{S}$, Wigzell $\mathrm{H}$, et al. The expression of the gene coding for the antibacterial peptide LL-37 is induced in human keratinocytes during inflammatory disorders. J Biol Chem. 1997;272(24): 15258-63.

50. Dorschner RA, Pestonjamasp VK, Tamakuwala S, Ohtake T, Rudisill J, Nizet V, et al. Cutaneous injury induces the release of cathelicidin anti-microbial peptides active against group A Streptococcus. J Invest Dermatol. 2001;117(1):91-7.

51. Wang TT, Nestel FP, Bourdeau V, Nagai Y, Wang Q, Liao J, et al. Cutting edge: 1,25-dihydroxyvitamin D3 is a direct inducer of antimicrobial peptide gene expression. J Immunol. 2004; 173(5):2909-12.

52. van der Does AM, Bergman $\mathrm{P}$, Agerberth $\mathrm{B}$, Lindbom L. Induction of the human cathelicidin LL-37 as a novel treatment against bacterial infections. J Leukoc Biol. 2012;92(4):735-42.

53. Nizet V, Ohtake T, Lauth X, Trowbridge J, Rudisill J, Dorschner RA, et al. Innate antimicrobial peptide protects the skin from invasive bacterial infection. Nature. 2001;414(6862):454-7.
54. Iimura M, Gallo RL, Hase K, Miyamoto Y, Eckmann L, Kagnoff MF. Cathelicidin mediates innate intestinal defense against colonization with epithelial adherent bacterial pathogens. J Immunol. 2005;174(8):4901-7.

55. Kovach MA, Ballinger MN, Newstead MW, Zeng X, Bhan U, $\mathrm{Yu}$ FS, et al. Cathelicidin-related antimicrobial peptide is required for effective lung mucosal immunity in Gram-negative bacterial pneumonia. J Immunol. 2012;189(1):304-11.

56. De Y, Chen Q, Schmidt AP, Anderson GM, Wang JM, Wooters $\mathrm{J}$, et al. LL-37, the neutrophil granule- and epithelial cellderived cathelicidin, utilizes formyl peptide receptor-like 1 (FPRL1) as a receptor to chemoattract human peripheral blood neutrophils, monocytes, and T cells. J Exp Med. 2000;192(7): 1069-74.

57. Scott MG, Davidson DJ, Gold MR, Bowdish D, Hancock RE. The human antimicrobial peptide LL-37 is a multifunctional modulator of innate immune responses. J Immunol. 2002; 169(7):3883-91.

58. Davidson DJ, Currie AJ, Reid GS, Bowdish DM, MacDonald $\mathrm{KL}$, Ma RC, et al. The cationic antimicrobial peptide LL-37 modulates dendritic cell differentiation and dendritic cellinduced T cell polarization. J Immunol. 2004;172(2):1146-56.

59. Lande R, Gregorio J, Facchinetti V, Chatterjee B, Wang YH, Homey B, et al. Plasmacytoid dendritic cells sense self-DNA coupled with antimicrobial peptide. Nature. 2007;449(7162): 564-9.

60. Heilborn JD, Nilsson MF, Jimenez CI, Sandstedt B, Borregaard $\mathrm{N}$, Tham E, et al. Antimicrobial protein hCAP18/LL-37 is highly expressed in breast cancer and is a putative growth factor for epithelial cells. Int J Cancer. 2005;114(5):713-9.

61. Koczulla R, Von Degenfeld G, Kupatt C, Krotz F, Zahler S, Gloe T, et al. An angiogenic role for the human peptide antibiotic LL-37/hCAP-18. J Clin Invest. 2003;111(11):1665-72.

62. Li HN, Barlow PG, Bylund J, Mackellar A, Bjorstad A, Conlon $\mathrm{J}$, et al. Secondary necrosis of apoptotic neutrophils induced by the human cathelicidin LL-37 is not proinflammatory to phagocytosing macrophages. J Leukoc Biol. 2009;86(4): 891-902.

63. Barlow PG, Beaumont PE, Cosseau C, Mackellar A, Wilkinson TS, Hancock RE, et al. The human cathelicidin LL-37 preferentially promotes apoptosis of infected airway epithelium. Am J Respir Cell Mol Biol. 2010;43(6):692-702.

64. Daher KA, Selsted ME, Lehrer RI. Direct inactivation of viruses by human granulocyte defensins. J Virol. 1986;60(3):1068-74.

65. Hazrati E, Galen B, Lu W, Wang W, Ouyang Y, Keller MJ, et al. Human alpha- and beta-defensins block multiple steps in herpes simplex virus infection. J Immunol. 2006;177(12): 8658-66.

66. Yasin B, Wang W, Pang M, Cheshenko N, Hong T, Waring AJ, et al. Theta defensins protect cells from infection by herpes simplex virus by inhibiting viral adhesion and entry. J Virol. 2004:78(10):5147-56.

67. Lehrer RI, Jung G, Ruchala P, Andre S, Gabius HJ, Lu W. Multivalent binding of carbohydrates by the human alpha-defensin, HD5. J Immunol. 2009;183(1):480-90.

68. Nakashima H, Yamamoto N, Masuda M, Fujii N. Defensins inhibit HIV replication in vitro. AIDS. 1993;7(8):1129.

69. Zhang L, Yu W, He T, Yu J, Caffrey RE, Dalmasso EA, et al. Contribution of human alpha-defensin 1,2, and 3 to the antiHIV-1 activity of CD8 antiviral factor. Science. 2002; 298(5595):995-1000.

70. Zhang L, Lopez P, He T, Yu W, Ho DD. Retraction of an interpretation. Science. 2004;303(5657):467.

71. Kuhn L, Trabattoni D, Kankasa C, Semrau K, Kasonde P, Lissoni $\mathrm{F}$, et al. Alpha-defensins in the prevention of HIV 
transmission among breastfed infants. J Acquir Immune Defic Syndr. 2005;39(2):138-42.

72. Demirkhanyan LH, Marin M, Padilla-Parra S, Zhan C, Miyauchi $\mathrm{K}$, Jean-Baptiste M, et al. Multifaceted mechanisms of HIV-1 entry inhibition by human alpha-defensin. $\mathrm{J}$ Biol Chem. 2012;287(34):28821-38.

73. Wu Z, Cocchi F, Gentles D, Ericksen B, Lubkowski J, Devico A, et al. Human neutrophil alpha-defensin 4 inhibits HIV-1 infection in vitro. FEBS Lett. 2005;579(1):162-6.

74. Chang TL, Vargas J Jr, DelPortillo A, Klotman ME. Dual role of alpha-defensin-1 in anti-HIV-1 innate immunity. J Clin Invest. 2005;115(3):765-73.

75. Furci L, Sironi F, Tolazzi M, Vassena L, Lusso P. Alphadefensins block the early steps of HIV-1 infection: interference with the binding of gp120 to CD4. Blood. 2007;109(7):2928-35.

76. Guo CJ, Tan N, Song L, Douglas SD, Ho WZ. Alpha-defensins inhibit HIV infection of macrophages through upregulation of CC-chemokines. AIDS. 2004;18(8):1217-8.

77. Lawn SD, Butera ST, Folks TM. Contribution of immune activation to the pathogenesis and transmission of human immunodeficiency virus type 1 infection. Clin Microbiol Rev. 2001;14(4):753-77.

78. Hubert P, Herman L, Maillard C, Caberg JH, Nikkels A, Pierard $\mathrm{G}$, et al. Defensins induce the recruitment of dendritic cells in cervical human papillomavirus-associated (pre)neoplastic lesions formed in vitro and transplanted in vivo. FASEB J. 2007;21(11):2765-75.

79. Rapista A, Ding J, Benito B, Lo YT, Neiditch MB, Lu W, et al. Human defensins 5 and 6 enhance HIV-1 infectivity through promoting HIV attachment. Retrovirology. 2011;8:45.

80. Schnapp D, Harris A. Antibacterial peptides in bronchoalveolar lavage fluid. Am J Respir Cell Mol Biol. 1998;19(3):352-6.

81. Ashitani J, Mukae H, Nakazato M, Ihi T, Mashimoto H, Kadota $\mathrm{J}$, et al. Elevated concentrations of defensins in bronchoalveolar lavage fluid in diffuse panbronchiolitis. Eur Respir J. 1998;11(1):104-11.

82. Singh PK, Jia HP, Wiles K, Hesselberth J, Liu L, Conway BA, et al. Production of beta-defensins by human airway epithelia. Proc Natl Acad Sci U S A. 1998;95(25):14961-6.

83. Hartshorn KL, White MR, Tecle T, Holmskov U, Crouch EC. Innate defense against influenza A virus: activity of human neutrophil defensins and interactions of defensins with surfactant protein D. J Immunol. 2006;176(11):6962-72.

84. Tecle T, White MR, Gantz D, Crouch EC, Hartshorn KL. Human neutrophil defensins increase neutrophil uptake of influenza A virus and bacteria and modify virus-induced respiratory burst responses. J Immunol. 2007;178(12):8046-52.

85. Leikina E, Delanoe-Ayari H, Melikov K, Cho MS, Chen A, Waring AJ, et al. Carbohydrate-binding molecules inhibit viral fusion and entry by crosslinking membrane glycoproteins. Nat Immunol. 2005;6(10):995-1001.

86. Caton AJ, Brownlee GG, Yewdell JW, Gerhard W. The antigenic structure of the influenza virus A/PR/8/34 hemagglutinin (H1 subtype). Cell. 1982;31(2 Pt 1):417-27.

87. Salvatore M, Garcia-Sastre A, Ruchala P, Lehrer RI, Chang T, Klotman ME. alpha-Defensin inhibits influenza virus replication by cell-mediated mechanism(s). J Infect Dis. 2007;196(6):835-43.

88. Sieczkarski SB, Brown HA, Whittaker GR. Role of protein kinase $\mathrm{C}$ betaII in influenza virus entry via late endosomes. J Virol. 2003;77(1):460-9.

89. Doss M, White MR, Tecle T, Gantz D, Crouch EC, Jung G, et al. Interactions of alpha-, beta-, and theta-defensins with influenza $\mathrm{A}$ virus and surfactant protein D. J Immunol. 2009;182(12):7878-87.

90. Smith JG, Nemerow GR. Mechanism of adenovirus neutralization by human alpha-defensins. Cell Host Microbe. 2008;3(1): 11-9.
91. Gropp R, Frye M, Wagner TO, Bargon J. Epithelial defensins impair adenoviral infection: implication for adenovirus-mediated gene therapy. Hum Gene Ther. 1999;10(6):957-64.

92. Buck CB, Day PM, Thompson CD, Lubkowski J, Lu W, Lowy DR, et al. Human alpha-defensins block papillomavirus infection. Proc Natl Acad Sci U S A. 2006;103(5):1516-21.

93. Dugan AS, Maginnis MS, Jordan JA, Gasparovic ML, Manley $\mathrm{K}$, Page R, et al. Human alpha-defensins inhibit BK virus infection by aggregating virions and blocking binding to host cells. J Biol Chem. 2008;283(45):31125-32.

94. Smith JG, Silvestry M, Lindert S, Lu W, Nemerow GR, Stewart PL. Insight into the mechanisms of adenovirus capsid disassembly from studies of defensin neutralization. PLoS Pathog. 2010;6(6):e1000959.

95. Bastian A, Schafer H. Human alpha-defensin 1 (HNP-1) inhibits adenoviral infection in vitro. Regul Pept. 2001;101(1-3): 157-61.

96. Harvey SA, Romanowski EG, Yates KA, Gordon YJ. Adenovirus-directed ocular innate immunity: the role of conjunctival defensin-like chemokines (IP-10, I-TAC) and phagocytic human defensin-alpha. Invest Ophthalmol Vis Sci. 2005;46(10): 3657-65.

97. Gounder AP, Wiens ME, Wilson SS, Lu W, Smith JG. Critical determinants of human alpha-defensin 5 activity against nonenveloped viruses. J Biol Chem. 2012;287(29):24554-62.

98. Nguyen EK, Nemerow GR, Smith JG. Direct evidence from single-cell analysis that human $\{$ alpha $\}$-defensins block adenovirus uncoating to neutralize infection. J Virol. 2010;84(8): 4041-9.

99. Chong KT, Thangavel RR, Tang X. Enhanced expression of murine beta-defensins (MBD-1, -2,- 3, and -4) in upper and lower airway mucosa of influenza virus infected mice. Virology. 2008;380(1):136-43.

100. Quinones-Mateu ME, Lederman MM, Feng Z, Chakraborty B, Weber J, Rangel HR, et al. Human epithelial beta-defensins 2 and 3 inhibit HIV-1 replication. AIDS. 2003;17(16):F39-48.

101. Duits LA, Nibbering PH, van Strijen E, Vos JB, MannesseLazeroms SP, van Sterkenburg MA, et al. Rhinovirus increases human beta-defensin-2 and -3 mRNA expression in cultured bronchial epithelial cells. FEMS Immunol Med Microbiol. 2003;38(1):59-64.

102. Proud D, Sanders SP, Wiehler S. Human rhinovirus infection induces airway epithelial cell production of human beta-defen$\sin 2$ both in vitro and in vivo. J Immunol. 2004;172(7): 4637-45.

103. Kota S, Sabbah A, Chang TH, Harnack R, Xiang Y, Meng X, et al. Role of human beta-defensin-2 during tumor necrosis factor-alpha/NF-kappaB-mediated innate antiviral response against human respiratory syncytial virus. J Biol Chem. 2008; 283(33):22417-29.

104. Nittayananta W, Kemapunmanus M, Amornthatree K, Talungchit S, Sriplung H. Oral human beta-defensin 2 in HIV-infected subjects with long-term use of antiretroviral therapy. J Oral Pathol Med. 2013;42(1):53-60.

105. Sun L, Finnegan CM, Kish-Catalone T, Blumenthal R, Garzino-Demo P, La Terra Maggiore GM, et al. Human betadefensins suppress human immunodeficiency virus infection: potential role in mucosal protection. J Virol. 2005;79(22): 14318-29.

106. Feng Z, Dubyak GR, Lederman MM, Weinberg A. Cutting edge: human beta defensin 3-a novel antagonist of the HIV-1 coreceptor CXCR4. J Immunol. 2006;177(2):782-6.

107. Hardwick RJ, Amogne W, Mugusi S, Yimer G, Ngaimisi E, Habtewold A, et al. beta-Defensin genomic copy number is associated with HIV load and immune reconstitution in subsaharan Africans. J Infect Dis. 2012;206(7):1012-9. 
108. Zapata W, Rodriguez B, Weber J, Estrada H, Quinones-Mateu ME, Zimermman PA, et al. Increased levels of human betadefensins mRNA in sexually HIV-1 exposed but uninfected individuals. Curr HIV Res. 2008;6(6):531-8.

109. Ryan LK, Dai J, Yin Z, Megjugorac N, Uhlhorn V, Yim S, et al. Modulation of human beta-defensin-1 (hBD-1) in plasmacytoid dendritic cells (PDC), monocytes, and epithelial cells by influenza virus, Herpes simplex virus, and Sendai virus and its possible role in innate immunity. J Leukoc Biol. 2011;90(2): 343-56.

110. Gong T, Jiang Y, Wang Y, Yang D, Li W, Zhang Q, et al. Recombinant mouse beta-defensin 2 inhibits infection by influenza A virus by blocking its entry. Arch Virol. 2010;155(4): 491-8.

111. Jiang Y, Yang D, Li W, Wang B, Jiang Z, Li M. Antiviral activity of recombinant mouse beta-defensin 3 against influenza A virus in vitro and in vivo. Antivir Chem Chemother. 2012;22(6):255-62.

112. Becker S, Quay J, Soukup J. Cytokine (tumor necrosis factor, IL-6, and IL-8) production by respiratory syncytial virus-infected human alveolar macrophages. J Immunol. 1991;147(12): 4307-12.

113. Howell MD, Streib JE, Leung DY. Antiviral activity of human beta-defensin 3 against vaccinia virus. J Allergy Clin Immunol. 2007;119(4):1022-5.

114. Howell MD, Jones JF, Kisich KO, Streib JE, Gallo RL, Leung DY. Selective killing of vaccinia virus by LL-37: implications for eczema vaccinatum. J Immunol. 2004;172(3):1763-7.

115. Nomura I, Goleva E, Howell MD, Hamid QA, Ong PY, Hall CF, et al. Cytokine milieu of atopic dermatitis, as compared to psoriasis, skin prevents induction of innate immune response genes. J Immunol. 2003;171(6):3262-9.

116. Tang YQ, Yuan J, Osapay G, Osapay K, Tran D, Miller CJ, et al. A cyclic antimicrobial peptide produced in primate leukocytes by the ligation of two truncated alpha-defensins. Science. 1999;286(5439):498-502.

117. Cole AM, Hong T, Boo LM, Nguyen T, Zhao C, Bristol G, et al. Retrocyclin: a primate peptide that protects cells from infection by T- and M-tropic strains of HIV-1. Proc Natl Acad Sci USA. 2002;99(4):1813-8.

118. Brandt CR, Akkarawongsa R, Altmann S, Jose G, Kolb AW, Waring AJ, et al. Evaluation of a theta-defensin in a murine model of herpes simplex virus type 1 keratitis. Invest Ophthalmol Vis Sci. 2007;48(11):5118-24.

119. Munk C, Wei G, Yang OO, Waring AJ, Wang W, Hong T, et al. The theta-defensin, retrocyclin, inhibits HIV-1 entry. AIDS Res Hum Retroviruses. 2003;19(10):875-81.

120. Gallo SA, Wang W, Rawat SS, Jung G, Waring AJ, Cole AM, et al. Theta-defensins prevent HIV-1 Env-mediated fusion by binding gp41 and blocking 6-helix bundle formation. J Biol Chem. 2006;281(27):18787-92.

121. Owen SM, Rudolph DL, Wang W, Cole AM, Waring AJ, Lal $\mathrm{RB}$, et al. RC-101, a retrocyclin-1 analogue with enhanced activity against primary HIV type 1 isolates. AIDS Res Hum Retroviruses. 2004;20(11):1157-65.

122. Cole AL, Yang OO, Warren AD, Waring AJ, Lehrer RI, Cole AM. HIV-1 adapts to a retrocyclin with cationic amino acid substitutions that reduce fusion efficiency of gp41. J Immunol. 2006;176(11):6900-5.

123. Gupta P, Ratner D, Ding M, Patterson B, Rohan LC, Reinhart TA, et al. Retrocyclin RC-101 blocks HIV-1 transmission across cervical mucosa in an organ culture. J Acquir Immune Defic Syndr. 2012;60(5):455-61.

124. Cole AM, Patton DL, Rohan LC, Cole AL, Cosgrove-Sweeney $\mathrm{Y}$, Rogers NA, et al. The formulated microbicide RC-101 was safe and antivirally active following intravaginal application in pigtailed macaques. PLoS One. 2010;5(11):e15111.

125. Liang QL, Zhou K, He HX. Retrocyclin 2: a new therapy against avian influenza $\mathrm{H} 5 \mathrm{~N} 1$ virus in vivo and vitro. Biotechnol Lett. 2010;32(3):387-92.

126. Doss M, Ruchala P, Tecle T, Gantz D, Verma A, Hartshorn A, et al. Hapivirins and diprovirins: novel theta-defensin analogs with potent activity against influenza A virus. J Immunol. 2012;188(6):2759-68.

127. Miura TA, Holmes KV. Host-pathogen interactions during coronavirus infection of primary alveolar epithelial cells. J Leukoc Biol. 2009;86(5):1145-51.

128. Wohlford-Lenane CL, Meyerholz DK, Perlman S, Zhou H, Tran $\mathrm{D}$, Selsted ME, et al. Rhesus theta-defensin prevents death in a mouse model of severe acute respiratory syndrome coronavirus pulmonary disease. J Virol. 2009;83(21):11385-90.

129. Malm J, Sorensen O, Persson T, Frohm-Nilsson M, Johansson $\mathrm{B}$, Bjartell A, et al. The human cationic antimicrobial protein (hCAP-18) is expressed in the epithelium of human epididymis, is present in seminal plasma at high concentrations, and is attached to spermatozoa. Infect Immun. 2000;68(7):4297-302.

130. Levinson P, Kaul R, Kimani J, Ngugi E, Moses S, MacDonald $\mathrm{KS}$, et al. Levels of innate immune factors in genital fluids: association of alpha defensins and LL-37 with genital infections and increased HIV acquisition. AIDS. 2009;23(3):309-17.

131. Levinson P, Choi RY, Cole AL, Hirbod T, Rhedin S, Payne B, et al. HIV-neutralizing activity of cationic polypeptides in cervicovaginal secretions of women in HIV-serodiscordant relationships. PLoS One. 2012;7(2):e31996.

132. Bergman P, Walter-Jallow L, Broliden K, Agerberth B, Soderlund J. The antimicrobial peptide LL-37 inhibits HIV-1 replication. Curr HIV Res. 2007;5(4):410-5.

133. Wong JH, Legowska A, Rolka K, Ng TB, Hui M, Cho CH, et al. Effects of cathelicidin and its fragments on three key enzymes of HIV-1. Peptides. 2011;32(6):1117-22.

134. Barlow PG, Svoboda P, Mackellar A, Nash AA, York IA, Pohl $\mathrm{J}$, et al. Antiviral activity and increased host defense against influenza infection elicited by the human cathelicidin LL-37. PLoS One. 2011;6(10):e25333.

135. Tripathi S, Tecle T, Verma A, Crouch E, White M, Hartshorn KL. The human cathelicidin LL-37 inhibits influenza A viruses through a mechanism distinct from that of surfactant protein $D$ or defensins. J Gen Virol. 2013;94(Pt 1):40-9.

136. Mookherjee N, Brown KL, Bowdish DM, Doria S, Falsafi R, Hokamp K, et al. Modulation of the TLR-mediated inflammatory response by the endogenous human host defense peptide LL-37. J Immunol. 2006;176(4):2455-64.

137. Xagorari A, Chlichlia K. Toll-like receptors and viruses: induction of innate antiviral immune responses. Open Microbiol J. 2008;2:49-59.

138. Ganguly D, Chamilos G, Lande R, Gregorio J, Meller S, Facchinetti $V$, et al. Self-RNA-antimicrobial peptide complexes activate human dendritic cells through TLR7 and TLR8. J Exp Med. 2009;206(9):1983-94.

139. Lai Y, Adhikarakunnathu S, Bhardwaj K, Ranjith-Kumar CT, Wen Y, Jordan JL, et al. LL37 and cationic peptides enhance TLR3 signaling by viral double-stranded RNAs. PLoS One. 2011;6(10):e26632.

140. Filewod NC, Pistolic J, Hancock RE. Low concentrations of LL37 alter IL-8 production by keratinocytes and bronchial epithelial cells in response to proinflammatory stimuli. FEMS Immunol Med Microbiol. 2009;56(3):233-40.

141. Hasan M, Ruksznis C, Wang Y, Leifer CA. Antimicrobial peptides inhibit polyinosinic-polycytidylic acid-induced immune responses. J Immunol. 2011;187(11):5653-9. 
142. Hansdottir S, Monick MM, Hinde SL, Lovan N, Look DC, Hunninghake GW. Respiratory epithelial cells convert inactive vitamin $\mathrm{D}$ to its active form: potential effects on host defense. J Immunol. 2008;181(10):7090-9.

143. Mansbach JM, Piedra PA, Borregaard N, Martineau AR, Neuman MI, Espinola JA, et al. Serum cathelicidin level is associated with viral etiology and severity of bronchiolitis. J Allergy Clin Immunol. 2012;130(4):1007 e1-1008 e1.

144. Currie SM, Gwyer Findlay E, McHugh B, Mackellar A, Tian M, Wang $\mathrm{H}$, et al. The human cathelicidin LL-37 has antiviral properties against respiratory syncytial virus. Manuscript under revisions. 2013.

145. Schauber J, Gallo RL. Antimicrobial peptides and the skin immune defense system. J Allergy Clin Immunol. 2008;122(2): 261-6.
146. Howell MD, Gallo RL, Boguniewicz M, Jones JF, Wong C, Streib JE, et al. Cytokine milieu of atopic dermatitis skin subverts the innate immune response to vaccinia virus. Immunity. 2006;24(3):341-8.

147. Dean RE, O'Brien LM, Thwaite JE, Fox MA, Atkins H, Ulaeto DO. A carpet-based mechanism for direct antimicrobial peptide activity against vaccinia virus membranes. Peptides. 2010;31(11): 1966-72.

148. Varkey J, Nagaraj R. Antibacterial activity of human neutrophil defensin HNP-1 analogs without cysteines. Antimicrob Agents Chemother. 2005;49(11):4561-6. 